\title{
Dorota Michalak
}

Uniwersytet Łódzki

\section{KONSTRUKCJA INSTRUMENTU \\ ZABEZPIECZAJĄCEGO \\ PRZED NIEKORZYSTNYM WPLYWEM NIEKATASTROFICZNEGO RYZYKA POGODOWEGO}

\begin{abstract}
Streszczenie: Na świecie pogodowe instrumenty pochodne odgrywają istotną rolę przy zabezpieczaniu firm branży energetycznej. To właśnie ta branża była prekursorem stosowania derywatów pogodowych, a ich stworzenie było naturalną odpowiedzią na popyt. Celem artykułu jest odpowiedź na pytanie, czy przedsiębiorstwa branży energetycznej w Polsce również narażone są na negatywne oddziaływanie niekatastroficznego ryzyka pogodowego oraz jak mógłby wyglądać instrument niwelujący wpływ panujących warunków atmosferycznych, zabezpieczający przychody tej branży. Z przeprowadzonego badania ekonometrycznego wynika, że warunki pogodowe mają istotny wpływ na przychody firm branży energetycznej. Uzasadnione zatem jest rozważenie wprowadzenia pogodowych instrumentów pochodnych na polski rynek. Artykuł przedstawia teoretyczną konstrukcje derywatów pogodowych na rynku giełdowym i pozagiełdowym.
\end{abstract}

Słowa kluczowe: derywaty pogodowe, zarządzanie ryzykiem pogodowym, wpływ warunków atmosferycznych, branża energetyczna.

DOI: $10.15611 / \mathrm{e} 21.2014 .3 .07$

\section{Wstęp}

Sektor energetyczny był prekursorem rynku derywatów pogodowych. Wynika to $\mathrm{z}$ faktu, iż w wielu gałęziach tego sektora pogoda odgrywa istotną rolę. Zaczynając od elektrowni i ciepłowni, poprzez rafinerie i dilerów oleju, gazu i węgla, kończąc na stacjach benzynowych, można zaobserwować, jak bardzo branża ta jest zależna od warunków atmosferycznych. Ryzyko związane z działalnością operacyjną ciepłowni oraz elektrociepłowni to przede wszystkim ryzyko niesione przez zmiany poziomu sprzedaży ich produktu - energii cieplnej i elektrycznej.

Celem artykułu jest odpowiedź na pytanie, czy przedsiębiorstwa branży energetycznej w Polsce również narażone są na negatywne oddziaływanie niekatastroficz- 
nego ryzyka pogodowego ${ }^{1}$ oraz jak mógłby wyglądać instrument niwelujący wpływ panujących warunków atmosferycznych, zabezpieczający przychody tej branży. Aby na nie odpowiedzieć, przeprowadzono badanie ekonometryczne oraz skonstruowano instrument zabezpieczający dla łódzkiego przedsiębiorstwa energetycznego.

\section{Pogodowe instrumenty pochodne}

Demonopolizacja w energetyce - proces rozpoczęty w USA, w Europie rozwinięty w Wielkiej Brytanii, a potem podjęty w innych krajach Europy Zachodniej i Europy Środkowej - sprawiła, że długoterminowe rozwiązania proponowane przez zakłady ubezpieczeniowe przestały zaspokajać potrzeby sektora energetycznego. Każde odchylenie od średniej w czasie okresu letniego czy zimowego może mieć bezpośredni wpływ na zyski przedsiębiorstwa energetycznego. Poszukiwanie rozwiązań finansowych - i jednocześnie odchodzenie od tradycyjnych, wieloletnich form ubezpieczeń - stało się podstawą rozwoju nowego rynku zarządzania ryzykiem pogodowym [www.im.pwr.wroc.pl... 2012].

Aby derywat można było zaliczyć do instrumentów pochodnych, niezbędne jest spełnienie przez niego określonych warunków. Po pierwsze instrumentem bazowym powinna być zmienna, która ma wpływ na procesy gospodarcze oraz warunki ekonomicznego funkcjonowania części przedsiębiorstw. Jednocześnie powinna istnieć grupa klientów, którzy znają zasady jego funkcjonowania. Kolejnym czynnikiem warunkującym istnienie na stałe danego derywatu jest brak możliwości wpływu na kształtowanie się cen instrumentu bazowego wśród uczestników rynku, na którym funkcjonuje dany instrument.

Finansową umowę pogodowych instrumentów pochodnych można opisać jako taką umowę opartą na określonych zdarzeniach pogodowych, której wartość pieniężna jest uzależniona od wystąpienia lub nie danego zjawiska pogodowego. Warunki pogodowe, które są podstawą kontraktu pogodowego, są rozliczane na podstawie indeksu pogody, określonego jako wartość zmiennej pogody mierzonej w danym czasie i miejscu. W związku z tym elementem niezbędnym do skonstruowania derywatów pogodowych jest skwantyfikowanie czynników pogodowych w sposób umożliwiający przypisanie im określonych wartości pieniężnych.

Umowa derywatów pogodowych może być stosowana do zabezpieczenia przychodów przed niekorzystnym wpływem warunków pogodowych. Jeżeli działalność przedsiębiorstwa jest wrażliwa na wysokość temperatury, opady śniegu czy nasłonecznienie, zastosowanie pogodowego instrumentu pochodnego skonstruowanego na odpowiedniej zmiennej pogody może przyczynić się do zmniejszenia wahań zysku [Dischel, Barrieu 2002].

${ }^{1}$ Pojęcia ryzyka o charakterze niekatastroficznym używa się do opisu finansowych konsekwencji dla przedsiębiorstw, wywołanych takimi zdarzeniami, jak niespodziewane zmiany temperatury, opady deszczu i śniegu lub wiatr. 
Pogodowe instrumenty pochodne są instrumentami finansowymi, których wartość jest uzależniona od wartości meteorologicznych. Czynnikiem bazowym jest podstawowe zdarzenie meteorologiczne, które uznaje się za zdarzenie niekatastroficzne. Stosowanie pogodowych instrumentów pochodnych bazuje na standardowych praktykach zarządzania ryzykiem gospodarczym, takim jak ryzyko walutowe czy stopy procentowej.

Instrumenty bazowe derywatów pogodowych znacznie różnią się od innych stosowanych powszechnie w narzędziach pochodnych. Derywaty te dotyczą zjawisk atmosferycznych, a więc wartości nieekonomicznych, ale policzalnych. W ich przypadku nie jest możliwy zakup czy też sprzedaż czynnika pogodowego. Pogody nie można także magazynować. Wbudowanym instrumentem bazowym w przypadku kontraktów pogodowych są warunki pogodowe, o których dane są pobierane z określonych stacji meteorologicznych [Kupczyk 2003].

Przez derywat należy rozumieć konstrukcję cywilnoprawną uzależniającą wartość świadczenia od wartości instrumentu bazowego. W obecnym stanie prawnym derywaty mieszczą się w kategorii instrumentów finansowych (opcje i transakcje terminowe). Podstawą konstrukcji derywatu jest art. 353 k.c. (swoboda kontraktowania) i jest to tzw. umowa nienazwana, której niezbędnych elementów konstrukcyjnych nie przewiduje żadna z obowiązujących ustaw [Krause 2010].

Omawiany instrument finansowy jest rozliczany w formie pieniężnej, co oznacza, że posiada on tzw. charakter ,nierzeczywisty”. W przypadku derywatów „rzeczywistych" przedmiot umowy jest doręczany w wyniku jej wykonania (np. doręczenie walut obcych lub metali szlachetnych). Jednak w omawianym przypadku derywatów pogodowych następuje zdematerializowane (bezgotówkowe) rozliczenie wartości pieniężnej pomiędzy stronami kontraktu [Krause 2010].

\section{Wpływ temperatury i opadów na ilość energii sprzedawanej przez firmę Dalkia Lódź w latach 2006-2011 - badanie ekonometryczne}

Celem przeprowadzonego badania ekonometrycznego było określenie, jak panujące warunki atmosferyczne wpływają na wyniki firm energetycznych. Do badania wybrano dwa czynniki pogodowe: średnią miesięczną temperaturę oraz wysokość średnich miesięcznych opadów w okresie od 2006-2011. Wybór temperatury jako czynnika wpływającego nie budzi większych zastrzeżeń, wysokość opadów wymaga wyjaśnienia. Postanowiono zbadać wpływ opadów, ponieważ od ich intensywności uzależniona jest temperatura; siła opadów znacząco wpływa także na powstające szkody urządzeń energetycznych, co w rezultacie może przekładać się na zysk przedsiębiorstw omawianej branży.

W celu przeprowadzenia badania zgromadzono następujące dane:

- średnie miesięczne temperatury w województwie łódzkim w okresie od stycznia 2006 do grudnia 2011; 
$\underline{\text { Konstrukcja instrumentu zabezpieczającego przed niekorzystnym wpływem... }}$

- średnie miesięczne sumy opadów w województwie łódzkim w okresie od stycznia 2006 do grudnia 2011;

- ilość energii (w teradżulach) sprzedanej przez firmę Dalkia w Łodzi w okresie od stycznia 2006 do grudnia 2011.

Tabela 1. Ilość energii cieplnej (w teradżulach) sprzedanej przez firmę Dalkia w Łodzi w okresie od stycznia 2006 do grudnia 2011 (w TJ)

\begin{tabular}{|l|c|c|c|c|c|c|}
\hline \multicolumn{1}{|c|}{ Miesiąc } & 2006 & 2007 & 2008 & 2009 & 2010 & 2011 \\
\hline Styczeń & 2649,460 & 1847,767 & 1934,945 & 2188,770 & 2527,709 & 1945,039 \\
\hline Luty & 2081,346 & 1877,045 & 1654,728 & 1844,797 & 1866,589 & 2009,426 \\
\hline Marzec & 2037,486 & 1476,599 & 1710,594 & 1723,209 & 1667,989 & 1610,687 \\
\hline Kwiecień & 1067,046 & 987,939 & 1106,317 & 822,716 & 1011,958 & 863,617 \\
\hline Maj & 426,229 & 507,198 & 462,234 & 436,243 & 602,274 & 454,307 \\
\hline Czerwiec & 362,559 & 285,179 & 295.025 & 317,455 & 293,979 & 239,700 \\
\hline Lipiec & 256,599 & 272,541 & 253,622 & 254,569 & 224,530 & 247,623 \\
\hline Sierpień & 288,673 & 262,784 & 262,721 & 253,483 & 247,907 & 251,892 \\
\hline Wrzesień & 339,223 & 580,236 & 643,290 & 302,395 & 591,420 & 286,598 \\
\hline Październik & 789,580 & 1215,433 & 1099,898 & 1260,792 & 1321,800 & 1013,2185 \\
\hline Listopad & 1432,868 & 1762,841 & 1437,375 & 1400,989 & 1348,854 & 1453,438 \\
\hline Grudzień & 1622,406 & 1973,300 & 1814,756 & 1857,077 & 2223,749 & 1572,395 \\
\hline
\end{tabular}

Źródło: opracowanie własne na podstawie danych pozyskanych z IMGW.

Tabela 2. Średnia miesięczna temperatura w województwie łódzkim w okresie od stycznia 2006 do grudnia $2011\left(\mathrm{w}{ }^{\circ} \mathrm{C}\right)$

\begin{tabular}{|l|c|c|c|c|c|c|}
\hline \multicolumn{1}{|c|}{ Miesiąc } & 2006 & 2007 & 2008 & 2009 & 2010 & 2011 \\
\hline Styczeń & $-7,7$ & 3,4 & 1,5 & $-2,9$ & $-7,2$ & $-0,4$ \\
\hline Luty & $-2,8$ & 0 & 2,9 & $-0,9$ & $-1,4$ & $-3,5$ \\
\hline Marzec & $-0,6$ & 6,3 & 3,5 & 2,6 & 3,1 & 3,3 \\
\hline Kwiecień & 9,0 & 9,6 & 8,7 & 11,5 & 8,9 & 10,8 \\
\hline Maj & 13,7 & 15,1 & 13,5 & 13,2 & 12,4 & 14,0 \\
\hline Czerwiec & 17,6 & 18,4 & 18,1 & 15,4 & 17,1 & 18,5 \\
\hline Lipiec & 23,0 & 18,3 & 19,5 & 19,3 & 21,0 & 17,5 \\
\hline Sierpień & 17,1 & 18,4 & 18,2 & 18,5 & 18,7 & 18,7 \\
\hline Wrzesień & 16,1 & 12,7 & 12,6 & 15,0 & 12,1 & 14,7 \\
\hline Październik & 10,9 & 7,7 & 9,7 & 6,7 & 5,6 & 8,6 \\
\hline Listopad & 6,0 & 1,5 & 5,2 & 5,7 & 5,7 & 3,0 \\
\hline Grudzień & 3,8 & 0 & 1,3 & $-1,0$ & $-5,7$ & 2,5 \\
\hline
\end{tabular}

Źródło: opracowanie własne na podstawie danych pozyskanych z IMGiW. 
W niniejszym badaniu zastosowano jednorównaniowy liniowy model ekonometryczny o ogólnej postaci:

$$
\mathrm{Y}=f\left(\mathrm{X} 1, \mathrm{X} 2, \ldots, \mathrm{X}_{\mathrm{k}}, \varepsilon\right)
$$

gdzie: $\mathrm{Y}$ - zmienna objaśniana, $\mathrm{X} 1, \mathrm{X} 2, \ldots, \mathrm{X}_{\mathrm{k}}$ - nielosowe zmienne objaśniające, $\varepsilon$ - zmienna losowa (przypadkowa) o średniej zero i stałej wariancji, $f$-odpowiednia postać analityczna zależności między zmiennymi uwzględnionymi w modelu.

Ze względu na charakter danych (dane miesięczne) możliwe jest występowanie sezonowości. Analiza wartości zmiennej w czasie wskazuje na występowanie wahań sezonowych. W związku z tym do modelu wprowadzone zostały periodyczne zmienne $0-1$, po jednej dla każdego miesiąca. Jednak wprowadzenie dwunastu zmiennych 0-1 spowodowałoby występowanie zjawiska ścisłej współliniowości, albowiem sumują się one dla każdej obserwacji w próbie do wektora jednostkowego $\left(\Sigma \gamma_{\mathrm{i}}=1\right)$, identycznego jak wektor wyrazu wolnego. Aby ominąć pułapkę związaną ze zmiennymi 0-1 (dummy variable trap), należało pominąć zmienną dla jednej z kategorii [Gajda 2004a].

Ostatecznie szacowany model jest postaci:

$$
\mathrm{Y}_{\mathrm{t}}=\alpha_{0}+\beta_{1} \mathrm{X} 1+\beta_{2} \mathrm{X} 2+\gamma_{1} d m 2+\ldots \gamma_{11} d m 12+\varepsilon_{t},
$$

gdzie: $\mathrm{Y}_{\mathrm{t}}$ - ilość sprzedawanej energii (w TJ), X1 - temperatura $\left(\mathrm{w}^{\circ} \mathrm{C}\right), \mathrm{X} 2$ - opady (w $\mathrm{mm}), d m 2 \ldots d m 12$ - periodyczne zmienne zero-jedynkowe, $\alpha_{0}$ - wyraz wolny, $\beta_{1}, \beta_{2}$ - parametry stojące przy zmiennych objaśniających, $\gamma_{1}, \ldots, \gamma_{11}-$ parametry stojące przy zmiennych zero-jedynkowych.

Jako metodę estymacji wykorzystano metodę najmniejszych kwadratów, ponieważ [Welfe 2003]:

- model jest liniowy względem parametrów,

- liczba obserwacji $(n=72)$ jest większa od liczby szacowanych parametrów,

- między zmiennymi egzogenicznymi modelu nie ma zależności liniowych.

Metoda najmniejszych kwadratów (pełna nazwa: klasyczna metoda najmniejszych kwadratów błędów, KMNK) jest standardową metodą przybliżania rozwiązań układów nadokreślonych, tzn. zestawów równan, w których jest ich więcej niż zmiennych. Nazwa „najmniejsze kwadraty” oznacza, że końcowe rozwiązanie tą metodą minimalizuje sumę kwadratów błędów przy rozwiązywaniu każdego z równań. Ma ona na celu wyznaczenie linii regresji, linii trendu dla zebranych danych. Stosowana jest do oszacowania zależności liniowej, jak również nieliniowej [Welfe 2003].

\subsection{Specyfikacja modelu}

$\mathrm{Na}$ teoretycznych podstawach zaczerpniętych z literatury skonstruowany został model objaśniający ilość sprzedawanej energii w poszczególnych miesiącach. Na wy- 
bór zmiennych objaśniających oprócz wiedzy merytorycznej miały wpływ również względy formalno-statystyczne.

W ostatecznym zbiorze zmiennych pozostały zmienne o dużym stopniu zmienności, wysokiej względnej wartości informacyjnej mierzonej współczynnikiem zmienności o postaci:

$$
\mathrm{V}\left(W_{\mathrm{j}}\right)=\frac{S\left(W_{j}\right)}{\bar{W}_{j}},(j=1,2, \ldots, s),
$$

gdzie: $S\left(W_{j}\right)$ - odchylenie standardowe, $\bar{W}_{j}$ - średnia arytmetyczna.

Eliminacji podlegały zmienne, dla których współczynnik zmienności przyjmował wartości mniejsze od arbitralnie przyjętej liczby dodatniej. Powszechnie za granicę uznaje się wartość $\mathrm{V}(W j)=0,1$.

Kolejne kryterium to stopień skorelowania. Wybrane zmienne objaśniające powinny być słabo skorelowane ze sobą, gdyż zbyt silne powiązanie dwóch cech powoduje, że są nośnikami podobnych informacji oraz że są silnie skorelowane ze zmienną objaśnianą. W przypadku silnej korelacji pomiędzy zmiennymi zależnymi wybiera się „reprezentanta”, zazwyczaj kierując się przesłankami merytorycznymi.

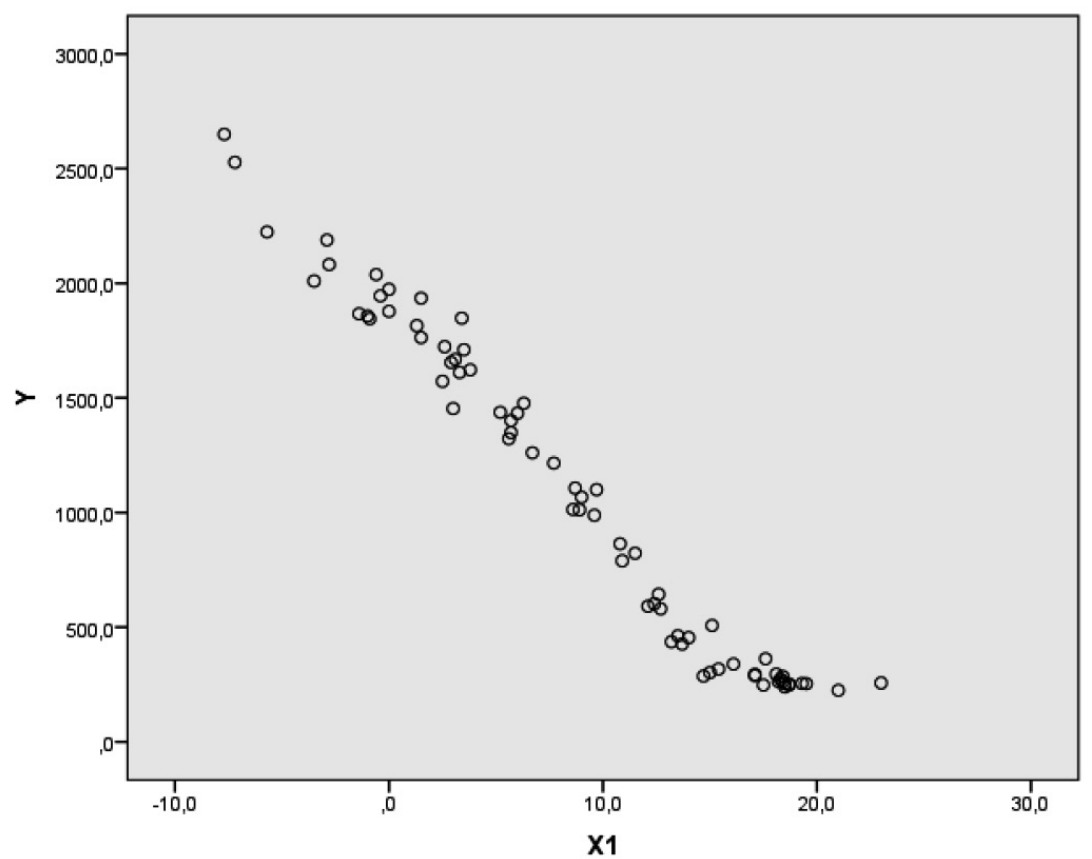

Rys. 1. Zależność pomiędzy temperaturą a ilością sprzedawanej energii

Źródło: opracowanie własne w programie SPSS. 


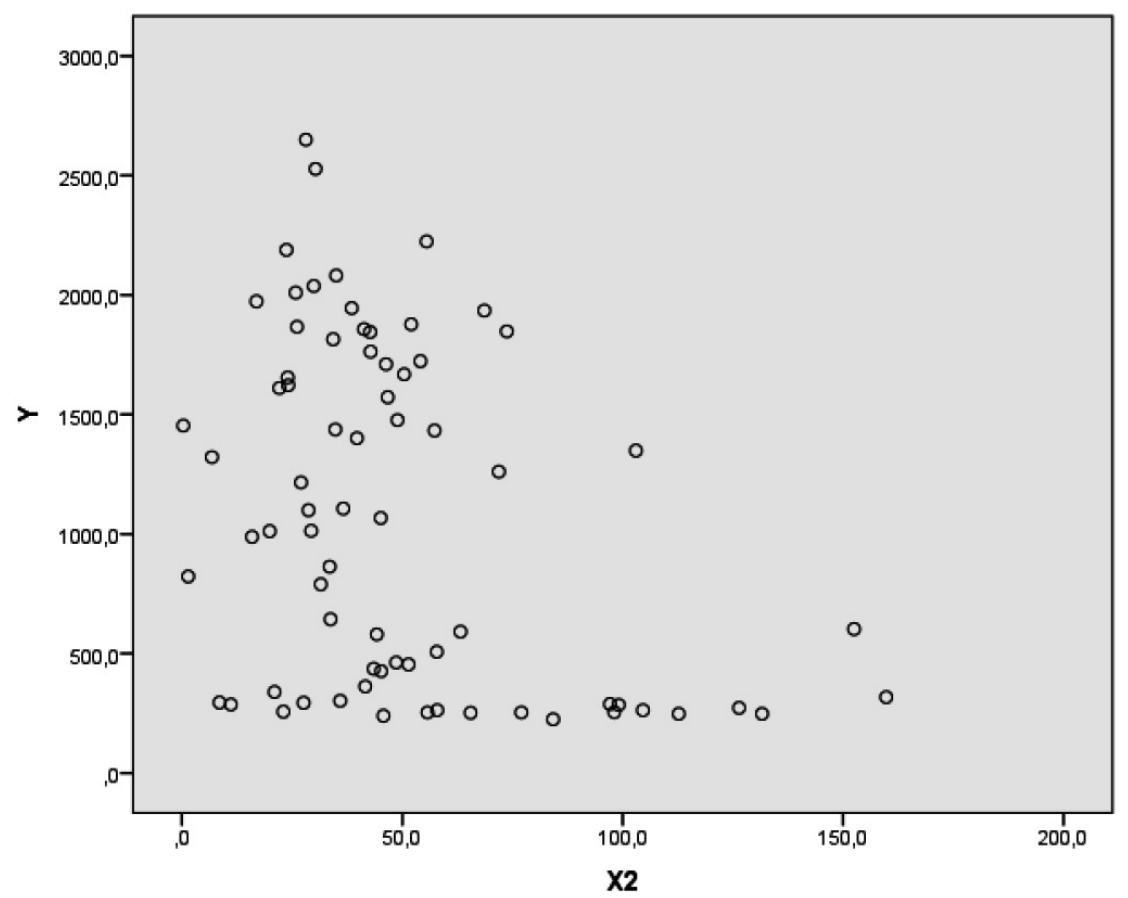

Rys. 2. Zależność pomiędzy opadami a ilością sprzedaży energii

Źródło: opracowanie własne w programie SPSS.

Na wykresach rozproszenia (rysunki 1 i 2 ) widoczna jest zależność pomiędzy zmienną endogeniczną a zmiennymi egzogenicznymi. Ocena wzrokowa sporządzonych wykresów pozwala przypuszczać, że istnieje ujemna zależność liniowa pomiędzy sprzedażą energii a temperaturą. Natomiast duże rozproszenia punktów na rys. 2 nie wskazuje na występowanie zależności pomiędzy sprzedażą energii a opadami.

Badanie wzajemnych powiązań między zmiennymi objaśniającymi polega na analizie macierzy R współczynników korelacji liniowej między wszystkimi zmiennymi objaśniającymi, przy czym oszacowane współczynniki korelacji spełniają warunek stabilności. Za wartość progową współczynnika korelacji na ogół przyjmuje się $r^{*}=0,7$.

\subsection{Estymacja modelu}

Model estymowano klasyczną metodą najmniejszych kwadratów przy użyciu oprogramowania Gretl. Równanie regresji opisujące sprzedaż energii elektrycznej składa się ostatecznie z dwóch zmiennych objaśniających oraz 11 zmiennych zero-jedynkowych. Wyniki modelowania widoczne są w tab. 3. 
Konstrukcja instrumentu zabezpieczającego przed niekorzystnym wpływem...

Tabela 3. Wyniki estymacji parametru dla modelu uwzględniającego temperaturę i opady, program Gretl

Model 1: Estymacja KMNK, wykorzystane obserwacje 2006:01-2011:12 (N = 72) Zmienna zależna (Y): Y

\begin{tabular}{|l|c|c|r|r|}
\hline \multicolumn{1}{|c|}{ Zmienna } & Współczynnik & Błąd stand. & $t$-Studenta & Wartość $\mathrm{p}$ \\
\hline Const & 2052,76 & 35,1232 & 58,4446 & $<0,00001$ \\
\hline $\mathrm{X} 1$ & $-67,1478$ & 4,39255 & $-15,2867$ & $<0,00001$ \\
\hline $\mathrm{X} 2$ & $-0,440947$ & 0,333707 & $-1,3214$ & 0,19157 \\
\hline$d m 2$ & $-212,45$ & 44,0163 & $-4,8266$ & 0,00001 \\
\hline$d m 3$ & $-126,151$ & 49,2859 & $-2,5596$ & 0,01311 \\
\hline$d m 4$ & $-410,268$ & 68,1483 & $-6,0202$ & $<0,00001$ \\
\hline$d m 5$ & $-625,453$ & 83,0994 & $-7,5266$ & $<0,00001$ \\
\hline$d m 6$ & $-549,472$ & 97,758 & $-5,6207$ & $<0,00001$ \\
\hline$d m 7$ & $-435,571$ & 108,032 & $-4,0319$ & 0,00016 \\
\hline$d m 8$ & $-527,291$ & 101,998 & $-5,1696$ & $<0,00001$ \\
\hline$d m 9$ & $-649,081$ & 82,8415 & $-7,8352$ & $<0,00001$ \\
\hline$d m 10$ & $-371,014$ & 63,0659 & $-5,8830$ & $<0,00001$ \\
\hline$d m 11$ & $-256,323$ & 52,7175 & $-4,8622$ & $<0,00001$ \\
\hline$d m 12$ & $-182,659$ & 44,8225 & $-4,0752$ & 0,00014 \\
\hline
\end{tabular}

\begin{tabular}{|l|c|l|l|r|}
\hline Średn. aryt. zm. zależnej & 1078,014 & & Odch. stand. zm. zależnej & 712,0142 \\
\hline Suma kwadratów reszt & 330494,0 & & Błąd standardowy reszt & 75,48624 \\
\hline Wsp. determ. R-kwadrat & 0,990818 & & Skorygowany R-kwadrat & 0,988760 \\
\hline F(13, 58) & 481,4495 & & Wartość p dla testu F & 5,48 e-54 \\
\hline Logarytm wiarygodności & $-405,7040$ & & Kryt. inform. Akaike'a & 839,4079 \\
\hline Kryt. bayes. Schwarza & 871,2813 & & Kryt. Hannana-Quinna & 852,0968 \\
\hline Autokorel. reszt - rho1 & 0,281691 & & Stat. Durbina-Watsona & 1,395211 \\
\hline
\end{tabular}

Źródło: opracowanie własne w programie Gretl.

Postać modelu po oszacowaniu:

$\hat{Y}=2052,76-67,15 \times X 1-0,44 \times X 2-212,45 \times d m 2-126,15 \times d m 3-410,27 \times d m 4$

$-625,45 \times d m 5-549,47 \times d m 6-435,57 \times d m 7-527,29 \times d m 8-649,08 \times d m 9$

$-371,01 \times d m 10-256,32 \times d m 11-182,66 \times d m 12$.

Tak oszacowane równanie można poddać interpretacji z ekonomicznego punktu widzenia. 
Wyraz wolny zwykle nie posiada interpretacji. W tym przypadku parametr á równy 2052,76 oznacza ilość sprzedaży energii, przy założeniu, że wartości pozostałych zmiennych uwzględnionych w modelu będą równe 0 .

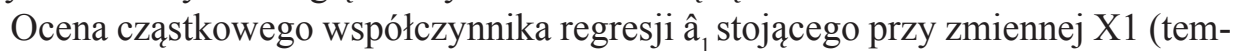
peratura) jest równa $-67,15$, a błąd tej oceny wynosi 4,39. Współczynnikowi temu można nadać następującą interpretację: jeżeli średnia miesięczna temperatura wzrasta o $1^{\circ} \mathrm{C}$, to średnio ilość sprzedawanej energii maleje o $67,15 \mathrm{TJ}$, pod warunkiem że wielkości innych zmiennych nie ulegną zmianie. W przypadku zmiennej X2 ocena cząstkowego współczynnika regresji jest równa $-0,44$ z błędem $\pm 0,33$, co pozwala na następującą interpretację merytoryczną: wraz ze wzrostem opadów o $1 \mathrm{~mm}$, ilość sprzedawanej energii maleje o $0,44 \mathrm{TJ}$, pod warunkiem że temperatura oraz zmienne sezonowe pozostaną niezmienione.

Interpretacja ocen parametrów przy periodycznych zmiennych zero-jedynkowych dokonywana jest jako charakterystyka rozbieżności pomiędzy efektem danego miesiąca a efektem miesiąca bazowego (który został pominięty, w tym przypadku dm1). Na przykład ocena parametru przy dm2 wskazuje, że sprzedaż energii w lutym jest o 212,45 TJ niższa w porównaniu z miesiącem bazowym, czyli styczniem.

\subsection{Dokładność szacunku parametrów strukturalnych}

Dla otrzymanych oszacowań przeprowadzono test istotności z wykorzystaniem statystyki $t$-Studenta. Postawione zostały następujące hipotezy:

$$
\mathrm{H}_{0}: b_{\mathrm{i}}=0 \text {, }
$$

wobec hipotezy alternatywnej:

$$
\mathrm{H}_{1}: b_{i} \neq 0 .
$$

Hipoteza zerowa wskazuje na to, iż zmienna $x_{i}$ związana $z$ parametrem $b_{i}$ nie wywiera wpływu na zmienną objaśnianą. O parametrze $b_{i}$ mówimy, że jest istotny (istotnie różni się od zera), jeśli w trakcie testowania hipotez odrzucimy hipotezę zerową na korzyść hipotezy alternatywnej. Oznacza to, że zmienna $x_{i}$ istotnie wpływa na zmienną objaśnianą [Gajda 2004b]. Sprawdzianem testu jest statystyka $t$-Studenta $\left(t_{i}\right)$.

Jeżeli $\left|t_{i}\right|<t_{\alpha}$ - przyjmujemy hipotezę zerową,

jeżeli $\left|t_{\mathrm{i}}\right|>t_{\alpha}$ - odrzucamy hipotezę zerową, przyjmując jednocześnie hipotezę alternatywną, która głosi, że parametr ten ma istotny wpływ na zmienną objaśnianą, gdzie: $t_{\alpha}$ - wartość krytyczna odczytana z tablicy rozkładu Studenta o T-K stopniach swobody ( $\mathrm{T}$ - liczba obserwacji, $\mathrm{K}$ - liczba szacowanych parametrów).

Dla oszacowanych współczynników otrzymano wartości statystyki $t$-Studenta równe odpowiednio: $a_{0}=58,44 ; \hat{a}_{1}=-15,28 ; \hat{a}_{2}=-1,32$. Przy założonym poziomie istotności $\alpha=0,05$ odczytujemy z tablic statystycznych wartość krytyczną. Wartość $t_{\alpha}$ odczytana z tablic wynosi 2,024. 
Porównując wyniki estymacji komputerowej z wartością krytyczną $t_{\alpha}$, należy stwierdzić, że w przypadku zmiennej X1 oraz wszystkich zmiennych sezonowych, wartość absolutna statystyki $\left|t_{\mathrm{i}}\right|$ jest większa od wartości krytycznej $t$; zatem hipotezy zerowe odrzucamy na korzyść alternatyw. Tym samym zmienne te istotnie wpływają na zmienną objaśnianą. Natomiast zmienna X2 jest nieistotna statystycznie.

\subsection{Weryfikacja merytoryczna parametrów}

Analizując model od strony merytorycznej, należy zwrócić uwagę na kierunki wpływu zmiennych egzogenicznych na zmienną endogeniczną. Z punktu widzenia przyjętych hipotez kierunki wpływu zmiennych egzogenicznych na zmienną endogeniczną w przypadku średniej miesięcznej temperatury są poprawne. Ujemny znak przy parametrze $\hat{a}_{1}$ potwierdza, iż w miarę wzrostu temperatury ilość sprzedanej energii maleje. Logicznego uzasadnienia nie ma natomiast ujemny znak przy parametrze $\hat{a}_{2}$, który świadczy o tym, że wzrost opadów powoduje spadek sprzedaży energii.

\subsection{Normalność rozkładu składnika losowego}

Głównym założeniem podlegającym sprawdzeniu jest normalność rozkładu składnika losowego, którego realizacjami są reszty z oszacowanego modelu. Służy do tego test Jarque'a-Bery (JB). Test ten pozwala przyjąć lub odrzucić hipotezę o normalności rozkładu reszt. Statystyka testująca ma w tym teście rozkład $\chi^{2}$ z 2 stopniami swobody.

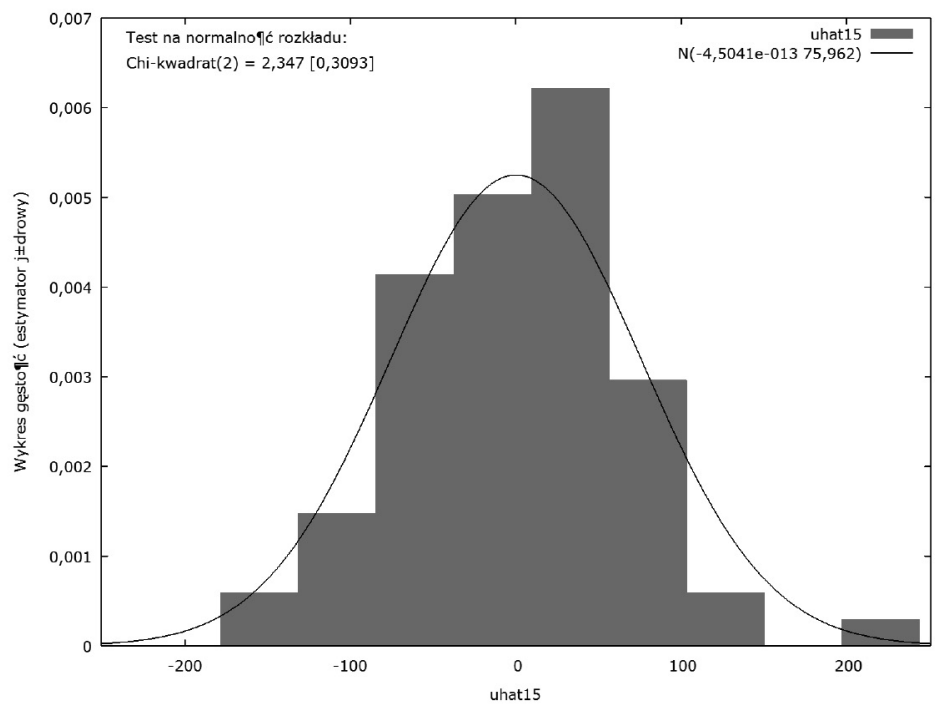

Rys. 3. Rozkładu reszt modelu

Źródło: opracowanie własne w programie Gretl. 
Formułujemy następującą parę hipotez:

$\mathrm{H}_{0}$ : reszty mają rozkład normalny.

$\mathrm{H}_{1}$ : reszty nie mają rozkładu normalnego.

Wartość sprawdzianu wynosi: JB $=2,347$.

Dla poziomu istotności $\alpha=0,05$ odczytujemy z tablic wartość krytyczną $\chi_{0,05,2}^{2}$ $=5,99$.

JB nie przekracza wartości krytycznej, zatem nie ma podstaw do odrzucenia hipotezy o normalności rozkładu badanej zmiennej i uznajemy, że rozkład reszt jest normalny.

\subsection{Dopasowanie modelu do danych}

Dokładność równania regresji, poza dokładnością szacunku parametrów strukturalnych, analizuje się również z punktu widzenia dopasowania równania do danych empirycznych. Oceny dopasowania dokonuje się m.in. za pomocą współczynnika determinacji $\mathrm{R}^{2}$ oraz odchylenia standardowego reszt [Gajda 2004b].

W oszacowanym modelu współczynnik determinacji przyjmuje wartość 0,99 . Oznacza to, że za pomocą równania udało się objaśnić 99\% zmienności zmiennej objaśnianej. Wartość ta wskazuje na bardzo dobre dopasowanie modelu do danych.

Syntetyczną charakterystyką dokładności, z jaką równanie opisuje zachowanie się zmiennej objaśnianej, jest wariancja reszt. Interpretacji podlega jednak jej pierwiastek, czyli błąd standardowy reszt. Błąd szacunku równania w przypadku niniejszego modelu wynosi 75,96, co oznacza, że szacując sprzedaż 1 TJ energii, zmieni się średni o $\pm 75,49 \mathrm{TJ}$.

\subsection{Heteroskedastyczność - test White'a}

Zjawisko heteroskedastyczności polega na niejednorodności wariancji składników losowych w obrębie próby. Przyczyną jest często sama natura zjawiska. Skutkiem heteroskedastyczności jest niespełnienie założeń KMNK, czego wynikiem jest to, że estymatory parametrów strukturalnych nie są efektywne, a estymatory ich wariancji są obciążone. Prowadzi to w konsekwencji do fałszywych informacji o poziomach istotności i wartości statystyk służących do testowania hipotez.

Testem służącym do weryfikacji założenia o stałości wariancji reszt jest test White'a, w którym szacowana jest regresja ze zmienną objaśnianą będącą resztami z pierwotnego modelu i zmiennymi objaśniającymi będącymi kwadratami i iloczynami krzyżowymi zmiennych objaśniających z pierwotnego modelu. Hipoteza zerowa mówi o tym, że reszty w modelu mają stałą wariancję (niezależną od zmiennych objaśniających):

$\mathrm{H}_{0}: \zeta^{2} \mathrm{i}=$ const (składnik losowy jest homoskedastyczny).

$\mathrm{H}_{1}: \zeta^{2} \mathrm{i} \neq$ const (składnik losowy jest heteroskedastyczny).

Statystka testująca ma rozkład $\zeta^{2}$ o $m-1$ stopniach swobody, gdzie $m$ to liczba zmiennych objaśniających w drugim modelu. 
Jeżeli wartość $p$-value $<0,05$, to odrzucamy $\mathrm{H}_{0}$

Prawdopodobieństwo, że wartość krytyczna testu jest większa od wartości statystyki testującej wynosi $14 \%(p=0,14)$. Na przyjętym poziomie istotności $5 \%$ należy przyjąć hipotezę zerową, mówiącą o braku występowania heteroskedastyczności.

\subsection{Autokorelacja składnika losowego - test Test Durbina-Watsona, test Liunga-Boxa}

Autokorelacja składnika losowego - składniki losowe różnych obserwacji są ze sobą skorelowane - skutkuje tym, że estymatory nie są efektywne, estymator wariancji jest obciążony, co najczęściej prowadzi do niedoszacowania błędów i zawyżenia $t$-statystyk [Gajda 2004a].

Do wykrywania autokorelacji zakłóceń rzędu pierwszego wykorzystuje się test Durbina-Watsona, który jest najpopularniejszym testem weryfikującym istnienie autokorelacji pierwszego stopnia. Testuje on hipotezy:

$\mathrm{H}_{0}: \rho=0$ (brak autokorelacji),

$\mathrm{H}_{1}: \rho>0$ (autokorelacja dodatnia),

$\rho<0$ (autokorelacja ujemna).

Podstawową zaletą testu jest to, że rozkład statystyki testowej $D W$ jest znany zarówno dla małych, jak i dla dużych prób. Statystyka dana jest wzorem:

$$
D W=\frac{\sum_{t=2}^{n}\left(\varepsilon_{t}-\varepsilon_{t-1}\right)^{2}}{\sum_{t=1}^{n} \varepsilon_{t}^{2}} .
$$

Jeżeli dysponujemy dużą próbą, to czynnik po prawej stronie równania jest pomijalnie mały.

Formalnie można wykazać, że:

$$
D W \approx(1-\rho),
$$

gdzie: $\rho$-współczynnik autokorelacji reszt rzędu pierwszego.

Sposób testowania zależy od tego, czy sprawdzamy obecność dodatniej, czy ujemnej autokorelacji. Tablice rozkładu zawierają wartości krytyczne w zależności od liczby zmiennych w modelu $k$ i liczby obserwacji $n$. Dla każdej pary $k ; n$ dane są dwie wartości krytyczne $d ; d_{U}$.

Uzyskany współczynnik autokorelacji $(r h o=0,25)$ wskazuje na występowanie dodatniej autokorelacji. Wartość statystyki DW równa jest 1,43.

Z tablicy wartości krytycznych dla poziomu istotności $\alpha=0,05$ oraz $n=72 \mathrm{i}$ $k=12$, odczytano wartości $d_{L}=1,25$ oraz $d_{U}=2,01$.

Wartość sprawdzianu DW wpada do przedziału niekonkluzywności $(1,25<1,43$ $<2,01$ ), który nie daje jednoznacznej odpowiedzi o występowaniu autokorelacji pierwszego rzędu. 
W takim przypadku należało zastosować inne testy stwierdzające występowanie autokorelacji wyższych rzędów. Na podstawie analizy funkcji autokorelacji cząstkowej można podejrzewać występowanie autokorelacji szóstego rzędu, o czym świadczy istotny współczynnik Q Liunga-Boxa przy opóźnieniu szóstym.

Hipotezy w teście Ljunga-Boxa są następujące:

$\mathrm{H}_{0}: \rho_{i}=0$ (brak autokorelacji składnika losowego),

$\mathrm{H}_{1}: \rho_{i} \neq 0$ (występuje autokorelacja),

gdzie: $T$ - liczba obserwacji, $m$ - badany rząd autokorelacji, $\rho_{i}-$ współczynnik autokorelacji $i$-tego rzędu.

Statystyka weryfikująca jest postaci:

$$
Q=n(n+2) \sum_{k=1}^{h} \frac{\hat{\rho}_{k}^{2}}{n-k}
$$

Dla poziomu istotności $\alpha$ i $m$ stopni swobody z rozkładu $\chi^{2}$ odczytujemy wartość krytyczną $\chi^{2}$ o $m$ stopniach swobody. Jeżeli $Q \geq \chi^{2} \alpha(m)$, to odrzucamy H0, czyli występuje autokorelacja.

Jeżeli $Q<\chi^{2} \alpha(m)$, nie ma podstaw do odrzucenia H0, czyli nie ma autokorelacji.

Dla reszt oszacowanego modelu statystyka Q wyniosła 33,35 , co oznacza, że empiryczne prawdopodobieństwo wynosi $p$-value $=0,0008$ i jest bliskie zera. Należy zatem odrzucić hipotezę zerową na korzyść alternatywnej i uznać występowanie autokorelacji wyższych rzędów. Pozostałe testy na autokorelację wyższych rzędów również wskazują na jej występowanie.

Dla zwiększenia efektywności oszacowanego równania należy zastosować uogólnioną metodę najmniejszych kwadratów. Ze względu na występowanie autokorelacji wyższych rzędów najlepszą metodą estymacji jest uogólniona metoda Cochrane'a-Orcutta. W metodzie tej modyfikacji podlega sposób wyznaczania korekty procesów, ponieważ przyjmuje się występowanie autokorelacji wyższych rzędów [Kufel 2007].

Przeprowadzona analiza otrzymanych wyników pozwala zauważyć, że warunki pogodowe mają istotny wpływ na przychody firm branży energetycznej. Średnia miesięczna temperatura ma wpływ na liczbę jednostek energii sprzedanych przez firmę Dalkia. W miarę wzrostu temperatury liczba sprzedanych jednostek energii spada, w przypadku spadku temperatury sprzedaż energii rośnie. Wniosek ten ma logiczne i ekonomiczne uzasadnienie.

Średnie miesięczne opady nie mają wpływu na ilość sprzedanej energii. Nie można jednoznacznie określić, czy opady wpływają na wzrost czy też spadek sprzedanej energii, jest to uzależnione od temperatury oraz rodzaju występujących opadów. Stwierdzenie to zostało potwierdzone przez przeprowadzone testy istotności. 


\section{Konstrukcja instrumentu transferu ryzyka dla firmy Dalkia Kódź}

Dalkia Łódź jest firmą energetyczną narażoną na negatywne oddziaływanie niekatastroficznego ryzyka pogodowego. W historii swojej działalności firma nie zanotowała strat wywołanych zdarzeniami pogodowymi o charakterze katastroficznym, dlatego też nie zaleca się jej stosowania ubezpieczeń pogodowych.

Jak wynika z informacji uzyskanych od firmy Dalkia i z przeprowadzonego badania ekonometrycznego, czynnikiem pogodowym najsilniej wpływającym na ilość sprzedawanej energii jest temperatura powietrza.

Dalkia rok kalendarzowy dziali na dwa okresy: grzewczy, który trwa umownie od listopada do marca (ze względu na nieprzewidywalność pogody nie można określić konkretnych dat rozpoczęcia i zakończenia okresu grzewczego), i niegrzewczy. W okresie niegrzewczym ciepło produkowane jest tylko do podgrzewania wody oraz na potrzeby przemysłu. Jest to okres renowacji oraz napraw maszyn i urządzeń. W okresie grzewczym temperatura optymalna dla produkcji energii to $-5^{\circ} \mathrm{C}$, temperatura uważna za ekstremalnie niską to $-20^{\circ} \mathrm{C}$, temperatura od której następuje znacznie zmniejszenie zapotrzebowania na ciepło to $12^{\circ} \mathrm{C}$. Automatyka w węzłach cieplnych jest ustawiona $\mathrm{w}$ taki sposób, że przy temperaturze zewnętrznej wyższej niż $12^{\circ} \mathrm{C}$ ogrzewanie jest wyłączone. Przepływ zmniejsza się samoczynnie ze względu na zamykające się automatycznie sterowane zawory w węzłach cieplnych u odbiorców. W takiej sytuacji Dalkia musi pilnować, aby woda o tym mniejszym przepływie była podgrzana do temperatury zgodnej z tabelami regulacyjnymi. Pod uwagę należy brać także przyszłe zapotrzebowanie. Jeżeli w danym dniu temperatura osiąga poziom $12^{\circ} \mathrm{C}$, to należy pamiętać o prawdopodobnym spadku temperatury w nocy i o ewentualnej zmianie pogody, czyli o tym, że temperatura powietrza za jeden lub dwa dni może drastycznie spaść. W przypadku dużych różnic temperatur zewnętrznych zdarza się, że woda w dzień jest przegrzewana; mimo wyższej niż przewidywano temperatury powietrza nie można zaprzestać podgrzewania wody ze względu na nocne zapotrzebowanie. Każdy rozruch kotła obarczony jest ryzykiem wystąpienia awarii z uwagi na pojawiające się naprężenia. Dlatego też w takim okresie temperatura produkowana jest na poziomie dopasowanym, tak aby w przypadku spadku temperatury urządzenia były w stanie szybko dostosować swoją pracę do zapotrzebowania. Niestety oznacza to utratę energii i powrót ciepła do źródła.

Firma narażona na niekorzystne warunki pogodowe, która zna parametry tego ryzyka, może dokonać transakcji terminowej, zakupić kontrakt derywatów pogodowych, za pomocą których dokona transferu niechcianego ryzyka na rynek kapitałowy.

Derywaty pogodowe na świecie są instrumentem rynku giełdowego i pozagiełdowego. Ze względu na regulacje prawne obecnie nie ma możliwości zawarcia kontraktu pogodowego przez polskie firmy. Na Giełdzie Papierów Wartościowych w Warszawie nie występują kontrakty oparte na czynniku pogodowym, giełda 
w Chicago natomiast nie dokonuje transakcji derywatów pogodowych dla Polski. Gdyby to się jednak zmieniło, konstruując kontrakt pogodowych instrumentów pochodnych, należy wziąć pod uwagę: okres kontraktu (data początku i końca obowiązywania), podstawową i zapasową stację meteorologiczną, indeks bazowy (konstrukcja indeksu, która reprezentuje jedną lub więcej zmiennych pogodowych i jest podstawą rozliczenia finansowego kontraktu) oraz funkcję wypłaty (rodzaj instrumentu oraz wartość w jednostkach pieniężnych punktu indeksu).

Dla firmy Dalkia okresem kontraktu byłby okres od początku października do kwietnia. Podstawową stacją meteorologiczną byłaby stacja Łódź Lublinek, zapasową stacja w Piotrkowie Trybunalskim. Indeksem bazowym byłaby średnia dzienna temperatura, temperaturą graniczną byłoby $12^{\circ} \mathrm{C}$; rodzaj instrumentu to opcja. Dlatego też należy dostosować wzór HDD do zapotrzebowania firmy. Formuła indeksu miałaby następującą postać:

$$
\mathrm{HDD}=m^{*} 12^{\circ} \mathrm{C}-m^{*} \bar{y}_{t}
$$

gdzie $\bar{y}_{t}$ to średnia arytmetyczna z przeciętnych temperatur dziennych w okresie $m$ dni.

W analizowanym przypadku indeks HDD przyjmować będzie wartość dodatnią, gdy średnia temperatura powietrza danego dnia będzie niższa od $12^{\circ} \mathrm{C}, \mathrm{w}$ przeciwnym razie wartość indeksu HDD przyjmie wartość zerową. Wyliczone indeksy HDD zostają skumulowane dla okresów miesięcznych. Tabela 4 przedstawia zestawienie miesięcznych indeksów HDD dla firmy Dalkia Łódź w okresie od stycznia 2006 do grudnia 2011.

Tabela 4. Miesięczne wartości indeksu HDD dla firmy Dalkia za okres od stycznia 2006 do grudnia 2011

\begin{tabular}{|l|r|r|r|r|r|r|}
\hline \multicolumn{1}{|c|}{ Miesiąc } & 2006 & 2007 & 2008 & 2009 & 2010 & 2011 \\
\hline Styczeń & 610,7 & 266,6 & 325,5 & 461,9 & 595,2 & 384,4 \\
\hline Luty & 414,4 & 336 & 254,8 & 361,2 & 375,2 & 434 \\
\hline Marzec & 390,6 & 176,7 & 263,5 & 291,4 & 275,9 & 269,7 \\
\hline Kwiecień & 90 & 72 & 99 & 15 & 93 & 36 \\
\hline Maj & 0 & 0 & 0 & 0 & 0 & 0 \\
\hline Czerwiec & 0 & 0 & 0 & 0 & 0 & 0 \\
\hline Lipiec & 0 & 0 & 0 & 0 & 0 & 0 \\
\hline Sierpień & 0 & 0 & 0 & 0 & 0 & 0 \\
\hline Wrzesień & 0 & 0 & 0 & 0 & 0 & 0 \\
\hline Październik & 34,1 & 133,3 & 71,3 & 164,3 & 198,4 & 105,4 \\
\hline Listopad & 180 & 315 & 204 & 189 & 189 & 270 \\
\hline Grudzień & 254,2 & 372 & 331,7 & 403 & 548,7 & 294,5 \\
\hline
\end{tabular}

Źródło: opracowanie własne na podstawie danych pozyskanych z IMGiW (średnia miesięczna temperatura). 
Na podstawie wyliczonych wartości HDD jest możliwe wyznaczenie korelacji między wartością zgłoszonego zapotrzebowania na energię cieplną a wartością indeksu HDD, notowanymi w analizowanym okresie. Zależność tą prezentuje rys. 4 .

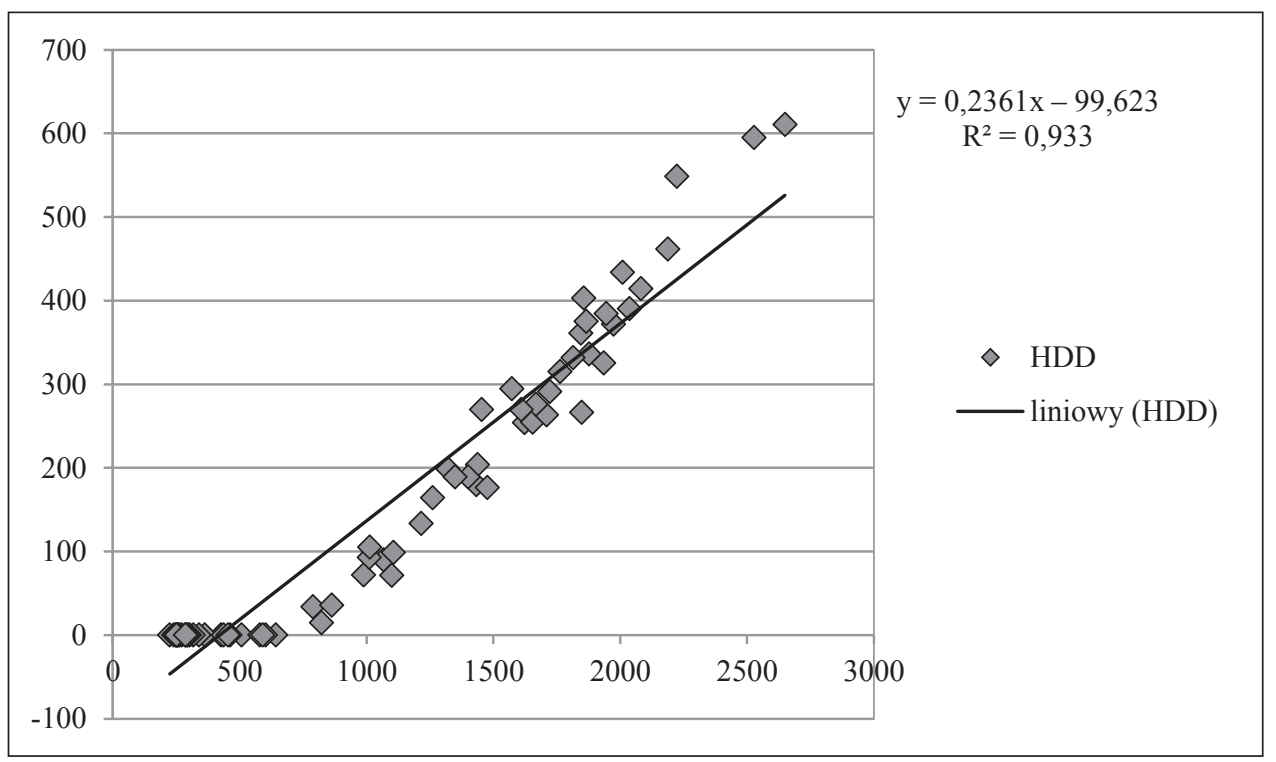

Rys. 4. Korelacja między wartością zapotrzebowania na energię cieplną zgłoszonego do fïmy Dalkia a wartością indeksu HDD

Źródło: opracowanie własne.

\begin{tabular}{|l|l|}
\hline \multicolumn{2}{|c|}{ Statystyki regresji } \\
\hline Wielokrotność R & 0,9659 \\
\hline R kwadrat & 0,932964 \\
\hline Dopasowany R kwadrat & 0,932006 \\
\hline Błąd standardowy & 45,37768 \\
\hline Obserwacje & 72 \\
\hline
\end{tabular}

\begin{tabular}{|l|c|c|c|c|c|}
\hline \multicolumn{1}{|c|}{ ANALIZA WARIANCJI } & & & & & \\
\hline & $d f$ & $S S$ & MS & F & Istotność F \\
\hline Regresja & 1 & 2006028 & 2006028 & 974,2097 & $8,19 \mathrm{E}-43$ \\
\hline Resztkowy & 70 & 144139,4 & 2059,134 & & \\
\hline Razem & 71 & 2150167 & & & \\
\hline
\end{tabular}


Analiza istotności współczynnika regresji pozwala odpowiedzieć na pytanie, czy związek między notowaną zmiennością ilości wyprodukowanej energii przez Dalkia Łódź a wartością współczynnika HDD jest liniowy i istotny. Oceniany współczynnik regresji został oszacowany na poziomie $0,236 \mathrm{TJ}$ z dokładnością średnio 0,007 TJ.

Wartość statystyki $t$ oceniającej istotność tego współczynnika, obliczonego na podstawie danych, wynosi 31,21 , a związany z nią poziom prawdopodobieństwa (z tablic rozkładu $t$-Studenta dla $n-k$ stopni swobody -70 ) wynosi $<0,05$, co oznacza, że współczynnik regresji dla zmiennej temperatury można uznać za istotny. Można zatem stwierdzić, że związek między ilością wyprodukowanej energii a wartością współczynnika HDD jest istotny i liniowy. W okresie od stycznia 2006 do grudnia 2012 przy wzroście indeksu HDD o jedną jednostkę oczekiwać należy wzrostu produkowanej energii cieplnej o 0,236 TJ. Współczynnik determinacji $\mathrm{R}^{2}$ wynosi 93,3, co pozwala stwierdzić, że 93,3\% zmienności wielkości wyprodukowanej energii w badanym okresie wyjaśnione zostało oszacowanym modelem. Pozostałe $6,7 \%$ tej zmienności spowodowane jest innymi czynnikami, nie uwzględnionymi w modelu.

W przypadku analizowanego przedsiębiorstwa średnia wielkość sprzedaży energii cieplnej w okresie od stycznia 2006 do grudnia 2011 kształtowała się na poziomie 1073,92 TJ. Powyższa wartość odpowiada wartości indeksu HDD na poziomie 154,87 . Aby zabezpieczyć się przed niekorzystnym wpływem temperatury powietrza na wysokość produkowanej energii cieplnej, Dalkia powinna dokonać sprzedaży siedmiomiesięcznego kontraktu, przy cenie wykonania na poziomie 154,87 HDD o wartości równej 1073,92 TJ.

W transakcji opcyjnej w sytuacji wystąpienia niekorzystnych warunków pogodowych, gdy wartość indeksu będzie niższa niż 154,87 HDD, straty wynikające ze zmniejszenia zapotrzebowania na energię cieplną będą rekompensowane przez wpływy związane z rozliczeniem zawartego kontraktu opcyjnego. W przypadku gdy okres grzewczy będzie korzystny dla przedsiębiorstwa (niskie temperatury odpowiadają wysokim wartością HDD), generowane będą przychody wyższe niż oczekiwano. Jedynym kosztem wynikającym z transakcji będzie wysokość zapłaconej premii.

$\mathrm{Na}$ rynku pozagiełdowym, gdzie możliwe jest lepsze dopasowanie instrumentu do potrzeb, dla firmy Dalkia możliwa jest konstrukcja instrumentu biorącego pod uwagę nie tylko plusową niekorzystną temperaturę w okresie grzewczym (czyli $12^{\circ} \mathrm{C}$ ), ale także najniższą (czyli $\left.-5^{\circ} \mathrm{C}\right)$. Formuła kontraktu ma następującą postać:

$$
\mathrm{HDD}=\sum_{\mathrm{t}=1}^{\mathrm{m}} \max \left(0,12^{\circ} \mathrm{C}-\mathrm{y}_{\mathrm{t}}\right)+\sum_{\mathrm{t}=1}^{\mathrm{m}} \max \left(0, \mathrm{y}_{\mathrm{t}}-5^{\circ} \mathrm{C}\right) .
$$

Tak skonstruowany kontrakt umożliwiłby uniknięcie strat wynikających ze zbyt niskiej i zbyt wysokiej temperatury. Dzięki temu mimo występowania niesprzyjających warunków pogodowych firma nie ponosiłaby strat finansowych, inaczej mówiąc, byłaby zabezpieczona przed niekatastroficznym ryzykiem pogodowym. 


\section{Zakończenie}

$\mathrm{Na}$ świecie pogodowe instrumenty pochodne odgrywają istotną rolę przy zabezpieczaniu firm branży energetycznej, zwłaszcza przedsiębiorstw zajmujących się dostarczaniem ciepła. To właśnie ta branża była prekursorem stosowania derywatów pogodowych, a ich stworzenie było naturalną odpowiedzią na popyt [Banks 2002]. Derywaty są także chętnie wykorzystywane przez przedsiębiorstwa z innych branż, takich jak: rolnictwo, budownictwo, transport, turystyka. Przeprowadzone badanie ekonometryczne wskazuje, że wysokość przychodów polskich przedsiębiorstw energetycznych również uzależniona jest od temperatury powietrza, jednak do tej pory brak jest udokumentowanych przykładów korzystania z omawianego instrumentu. Rozwój rynku derywatów pogodowych w Polsce może dokonać się przez wprowadzenie indeksów opartych na warunkach atmosferycznych do obrotu na GPW w Warszawie. Pozwoliłoby to na wykorzystanie istniejącej infrastruktury techniczno-organizacyjnej w zakresie rynku giełdowego instrumentów pochodnych. Ponadto rozszerzenie oferty rynku giełdowego uczyniłoby go bardziej atrakcyjnym dla jego uczestników. Jednak aby było to możliwe, w pierwszej kolejności muszą zajść zmiany w przepisach prawa, które obecnie pomijają możliwość zawierania kontraktów dla instrumentów pochodnych z pogodą jako czynnikiem bazowym. W Polsce głównymi aktami prawnymi dotyczącymi transakcji pochodnych są: Ustawa z dnia 12 marca 2004 roku o publicznym obrocie papierami wartościowymi oraz zmianie innych ustaw, Prawo bankowe, Prawo dewizowe, Rozporządzenie Rady Ministrów z 22 grudnia 1998 roku w sprawie określenia podmiotów uprawnionych do składania wniosku o wyrażenie zgody na wprowadzenie do publicznego obrotu praw pochodnych, Ustawa z dnia 21 sierpnia 1997 roku Prawo o publicznym obrocie papierami wartościowymi, oraz Ustawa z dnia 29 lipca 2005 roku o obrocie instrumentami finansowymi.

W krajach, w których kontrakty oparte na czynniku pogodowym zawierane są na szeroką skalę, instrument ten został ujęty w ramach legislacji. W prawie amerykańskim w Market Oversight Consolidation and OTC Derivatives Regulation Act wprowadzono zapis, który mówi, że instrument pochodny dotyczyć może jakiegokolwiek wskaźnika, który jest poza kontrolą którejkolwiek ze stron umowy. W ten sposób umożliwiono zawieranie transakcji z wykorzystaniem różnorodnych instrumentów bazowych, w tym również warunków atmosferycznych. W prawie angielskim w ustawie Finance Act 2002 wskazano wprost, że instrumenty pochodne obejmują również instrumenty oparte na czynniku pogodowym [Kluza 2003].

Instrument ten może stać się przedmiotem obrotu na rynku pozagiełdowym również poprzez zorganizowanie platformy internetowej, uwzględnienie derywatów pogodowych w ofercie międzybankowego rynku pozagiełdowego przez instytucje finansowe obsługujące duże firmy z branż szczególnie narażonych na ryzyko pogodowe lub też zorganizowanie specjalistycznego rynku derywatów pogodowych przez przedsiębiorstwa zainteresowane ograniczeniem tego ryzyka [Binkowski 2008]. 


\section{Literatura}

Banks E., Weather Risk Management, markets, products and applications, Palgrave, New York, 2002.

Binkowski P., Warunki tworzenia i perspektywy rozwoju rynku derywatów pogodowych na rynku krajowym, „Współczesna Ekonomia” 2008, nr 1(5).

Dischel R., Barrieu P., Financial weather contracts and their application in risk management, [w:] Climate Risk and The Weather Market - Financial Risk Management with Weather Hedges, Risk Books, London 2002.

Gajda J.B., Ekonometria, C.H. Beck, Warszawa 2004a.

Gajda J.B., Ekonometria. Wyktad i łatwe obliczenia w programie komputerowym, C.H. Beck, Warszawa 2004b.

Kluza S., Sławiński A., Arbitraż na rynku instrumentów procentowych, „Bank i Kredyt” 2003, nr 8.

Krause A., Derywaty pogodowe. Wybrane aspekty prawne, [w:] WRMA 11th European Meeting, Kraków 2010.

Kufel T., Ekonometria. Rozwiąywanie problemów z wykorzystaniem programu Gretl, Wydawnictwo Naukowe PWN, Warszawa 2007.

Kupczyk J., Analiza ekonometryczna indeksów pogodowych instrumentów pochodnych, Prace Naukowe Akademii Ekonomicznej we Wrocławiu nr 1006, Wrocław 2003.

Welfe A., Ekonometria, PWE, Warszawa 2003.

www.im.pwr.wroc.pl/ hugo/publ/.pdf, 4.11.2012

\section{Akty prawne}

Ustawa z dnia 12 marca 2004 r. o publicznym obrocie papierami wartościowymi, Dz.U. nr 64, poz. 594. Ustawa z dnia 21 sierpnia 1997 r. Prawo o publicznym obrocie papierami wartościowymi, Dz.U. nr 163, poz. 1155 .

Ustawa z dnia 27 lipca 2002 r. Prawo dewizowe, Dz.U. nr 160, poz. 1063.

Ustawa z dnia 29 lipca 2005 r. o obrocie instrumentami finansowymi, Dz.U. nr 183, poz. 1538.

Ustawa z dnia 29 sierpnia 1997 r. Prawo bankowe, Dz.U. nr 140, poz. 939.

\section{CONSTRUCTION OF HEDGING INSTRUMENT AGAINST ADVERSE EFFECTS OF NOT CATASTROPHIC WEATHER RISK}

Summary: In the world weather derivatives play an important role in securing companies from energy industry. That industry was a pioneer in the use of weather derivatives and their creation was a natural response to the demand for this type of protection against weather risk. The article aims are to answer the question whether the energy industry companies in Poland are also vulnerable to the negative impact of not catastrophic weather risk and how a hedge instrument, diminishing the effects of prevailing weather conditions and securing the revenues of the industry might look like-. Owing to the analysis of the obtained results, we can conclude that weather conditions have a significant impact on the revenues of power companies. It is therefore reasonable to consider the introduction of weather derivatives on the Polish market. This article presents theoretical constructs of weather derivatives on the stock market and outside it.

Keywords: weather derivatives, weather risk management, impact of weather conditions, energy sector. 